\title{
The Effect of Social Media Marketing to Satisfaction and Consumer Response: Examining the Roles of Perceived Value and Brand Equity as Mediation
}

\author{
Handri Dian Wahyudi; Cesya Rizkika Parahiyanti \\ Management Department, Universitas Negeri Malang, Indonesia \\ http://dx.doi.org/10.18415/ijmmu.v8i12.3210
}

\begin{abstract}
Social media has become a part of people's lives and an inseparable part of marketing strategies in the emerging digital era. This set of technologies creates new mechanisms and communication tools for companies to interact and engage with potential consumers. This study explores the effect of social media marketing (SMM) on satisfaction and consumer response through perceived value and brand equity. Based on an online survey of 325 users who follow smartphone brands on social media in Indonesia, data were collected and analyzed using partial least squares. The results show that SMM directly affects perceived value and brand equity and indirectly affects satisfaction and consumer response. This study emphasizes satisfaction and consumer response in responding to social media marketing by the company.
\end{abstract}

Keywords: Social Media Marketing; Perceived Value; Brand Equity; Satisfaction; Consumer Response

\section{Introduction}

The presence of social media creates a new era for companies and brands, forcing companies to seek new interactive ways to reach and engage their customers (Godey et al., 2016). The emergence of social media reflects people's need for interpersonal interaction. They added social media as an integral part of the marketing strategy and considered it a less expensive platform where marketers can carry out integrated marketing activities with minimal effort (Kim \& Ko, 2010). This phenomenon shows that companies are using social media as an essential part of their online marketing strategy.

The Internet has developed various forms of media and applications over time. It has changed the traditional human interactions of the past and also created new bridges for communication. With the popularity of the Internet and mobile technology and the widespread reliance on brand preferences on social media, sharing brand experiences and information has become a new field of brand marketing.

Social media marketing (SMM) complements traditional and digital marketing (Tuten \& Solomon, 2018). It monitors and facilitates customer communication, collaboration \& interaction with companies, brands \& other customers and drives their engagement. It also describes the customer's view of the company's various marketing activities on social media platforms. SMM is a challenge for marketing managers, which can be used as a powerful driver to obtain positive customer responses that can influence their purchase intentions, behavior, and decisions. It is a significant factor in building brands and creating long-term customer relationships (Ebrahim, 2020). 
Social media offers a variety of opportunities and benefits for successful brand management. A key challenge is measuring the impact of marketing managers' practices on social media. Kim and Ko (2010) identify five main strengths in SMM: entertainment, interaction, trendiness, customization, and word-of-mouth, which capture consumer perceptions of various marketing practices on social media and characterize product/brand social media marketing activities (Yadav \& Rahman, 2018). This activity stimulates consumer experience and impacts perceived value, brand equity and satisfaction, and consumer response.

Despite the various research that develops on social media, research on the impact of social media on satisfaction and consumer response simultaneously is still rarely found. This study emphasizes the impact of social media on the consumer side rather than on marketers. Likewise, research examining the effects of social media marketing from the perspective of the branding literature is also still exploratory and lacks empirical studies (Godey et al., 2016). Seo and Park (2018) also stated that studies on the impact of social media marketing on brand value and customer relationships are still unclear. This study contributes to the previous literature by offering a comprehensive framework that shows how social media marketing efforts affect brand equity and perceived value, which looks at consumer satisfaction and response.

\section{Literature Review}

\section{The Influence of Social Media Marketing to Perceived Value}

Gunelius (2011) states that social media marketing is a form of direct or indirect marketing used to build awareness, recognition, memory, and action for brands, businesses, products, people, or other entities. Social media usually uses tools from the social web, such as blogging, microblogging, social networking, social bookmarking, and content sharing.

In line with Chen and Lin's research (2019), it shows that social media marketing activities indirectly affect satisfaction through social identification and perceived value. At the same time, social identification and perceived value directly affect satisfaction, affecting sustained attention, participation intention, and purchase intention. Finally, the educational and management implications based on the empirical results of this study serve as a reference for improving social media marketing. Based on the research results that have been described, the first hypothesis is proposed as follows:

H1. Social media marketing has a positive effect on perceived value.

\section{The Influence of Social Media Marketing to Satisfaction}

Tuten (2008) states that social media marketing is a form of online advertising that uses social communities' cultural context, including social networks, virtual worlds, social news sites, and social opinion sites to meet communication goals. Hanaysha's research (2017) examines the influence of three marketing factors, namely social media marketing, price promotion, and corporate social responsibility, on customer satisfaction in the fast-food industry. The results of the study reveal that social media marketing has a significant positive effect on customer satisfaction. Other studies have also found that social media marketing plays an essential role in building customer satisfaction (Hanaysha, 2017; Sano, 2014). This study revealed that restaurant managers should take advantage of social media networks to reach out to their customers and interact with them to build higher satisfaction levels and respond to valuable suggestions that can benefit both stakeholders. Based on the discussion above, this study proposes $\mathrm{H} 2$ as follows:

H2. Social media marketing has a positive effect on consumer satisfaction.

The Influence of Social Media Marketing to Consumer Responses 
Social media marketing provides marketing information on the products being sold and intermediaries for online transaction activities with various payment features provided (Kim \& Ko, 2012). The ease of using social media and the intensity of promotions through social media marketing provided product information, prices, product choices to be sold, and product availability to transact lead to positive consumer responses because purchases can be easily and quickly made through technology media with the fast and convenient delivery process.

Consumer responses are a form of consumer behavior that provides feedback in the form of acceptance or rejection of product offerings that are given with the final result in making a purchase or not (Godey et al., 2016). Based on these discussions, this study expects marketing efforts on social media to directly impact consumer response, such as their preferences, premium prices, and loyalty. Then, the proposed hypothesis is as follows:

H3. Social media marketing has a positive effect on consumer response.

\section{The Influence of Social Media Marketing to Brand Equity}

Social media marketing is one of the promotional media used by companies to attract consumers. Social media marketing content is designed as attractive as possible with images. Quality offers advertising models to make it look attractive for consumers to make purchases (Godey et al., 2016). The company can provide information related to brands, products sold with various qualities and benefits offered through social media marketing.

This promotion process is related to the mention of the brand or the branding process to be easily remembered by consumers (Kim \& Ko, 2012). Marketing via social media marketing is considered capable of conveying information about the existence of products and brands, in particular, of boosting brand equity so that consumers can easily remember them. Marketing via social media marketing to inform the product brand can improve the brand image to understand it following the consumer market target intended by the company (Kim \& Hyun, 2011). Based on the discussion above, a hypothesis is proposed:

H4. Social media marketing has a positive effect on brand equity.

\section{The Influence of Perceived Value to Satisfaction}

Customer satisfaction has been defined as a cognitive or affective reaction that arises in response to a single or prolonged series of "service encounters" (Hu et al., 2009). The relationship between perceived value and customer satisfaction was debatable in the service marketing literature. It is argued that value directly influences how satisfied customers are with suppliers and that satisfaction depends on the value (Ravald \& Grönroos, 1996).

Zeithaml (1988) suggests that customers who feel 'value for money' are more satisfied than customers who feel they do not receive 'value for money'. Fornell et al. (1996) also support the positive effect of perceived value on customer satisfaction. Consumer satisfaction is generally interpreted as a post-consumption evaluation that depends on perceived quality and value. Based on the results of existing research, the following hypothesis is proposed:

H5. Perceived value has a positive effect on consumer satisfaction

\section{The Influence of Brand Equity to Consumer Responses}

Bruhn et al. (2012) examined the relationship between consumer-based brand equity and consumer response by conducting an online survey. Multiple mediation technique was used in this study. The dimensions of brand equity tested in this research survey are brand awareness and hedonic brand image and their relationship with consumer purchase intentions. The results showed a positive relationship between variables. 
Kim and Ko (2012) also conducted a research survey to prove a positive relationship between brand equity and consumer purchase intentions. Godey et al. (2016) explain the positive and significant relationship between social media marketing efforts and consumer behavior, influenced by the mediating impact of brand equity. Building a strong brand with positive equity will positively affect the company's performance by influencing consumer response to the brand (Buil et al., 2013). Based on the discussion above, the following hypothesis is proposed:

H6. Brand equity has a positive effect on consumer response

Figure 1 shows the model of research hypothesis

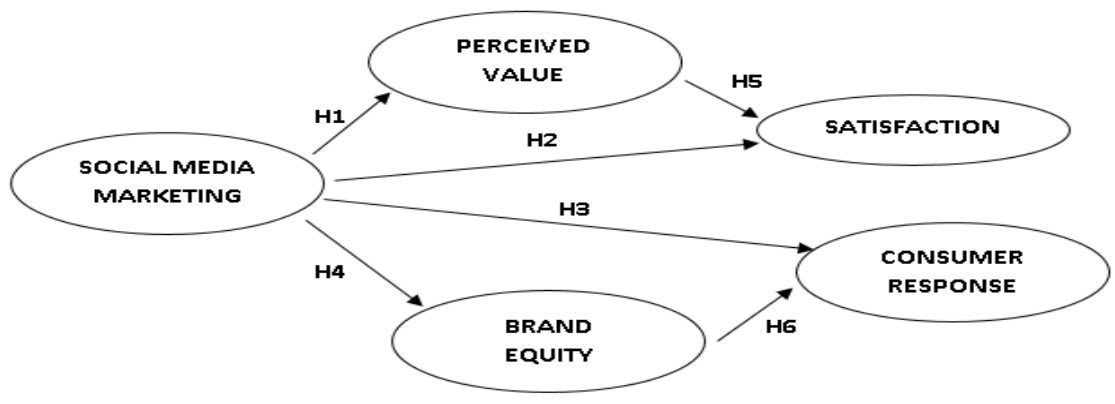

\section{Methods}

Fig. 1. Research Framework

This research is a quantitative and cross-sectional study. This research uses a convenient sampling technique to obtain respondents. The questionnaire was designed to conduct a survey, and data were collected from 421 respondents, of which only 325 respondents were valid. Respondents in this study were users of brand social media and followed the brand on social media websites. The brands selected for the research survey are Xiaomi and Realme. The target audience in this study are students and the general public who are social media followers of selected brands. The analyzed sample size was 325 , including 53\% women and $47 \%$ men. The majority of respondents $(68 \%)$ are aged 21-35 years. In terms of educational background, the largest group has completed education at one college or university (62\%), and the second largest group is high school graduates (17\%)

All measurement scales are adapted from previous studies. The Social Media Marketing (SMM) scale was adapted from research by Kim and Ko (2012), which stated that SMM has five dimensions: entertainment, interaction, trendiness, customization, and word-of-mouth. The brand equity scale was adopted from (Atilgan et al., 2005), which states that brand equity has four dimensions: perceived quality, brand awareness, brand loyalty, and brand associations. The consumer response scale is adapted from Belén del Río et al. (2001), Perceived Value adopted the measurement from Agarwal and Teas (2001), and satisfaction adopted the measurement from Cronin et al. (2000). All measurements in this study used a seven-point Likert Scale.

\section{Results}

This study uses Partial Least Square (PLS) analysis and is carried out in two stages. The first stage performs reliability and validity analysis, while the second stage estimates and verifies the structural model's path coefficient and explanatory power. The purpose of the two-stage analysis above is to confirm whether the constructs are reliable and valid, thereby verifying the relationship between the constructs (Anderson \& Gerbing, 1988).

\section{Outer Model and Scale Validation}

The tests carried out for the outer model include the reliability of each item and internal consistency, convergent validity, and discriminant validity of each construct. Item reliability was tested 
by looking at the factor loading of the questionnaire items. Factor loading shows the extent to which the construct can be measured with several questions, and the threshold value is 0.6 (Hair et al., 2014). The composite reliability of each construct is shown in Table 1. All construct composite reliability (CR) values are higher than 0.7 (Chin, 1998), indicating that the construct is internally consistent.

Related to convergent validity, in addition to measuring each question using factor loading and composite reliability, the AVE indicator for each construct is also considered. If the AVE value $>0.5$, this construct has good convergent validity (Fornell \& Larcker, 1981). It can be seen from Table 1 that the AVE for the constructs in this study is between 0.597 and 0.851 , indicating good convergent validity.

Table 1: Reliability and AVE of the outer model.

\begin{tabular}{llll}
\hline Construct & Cronbach's alpha & Composite reliability & AVE \\
\hline SMM & 0.846 & 0.891 & 0.624 \\
PV & 0.829 & 0.880 & 0.597 \\
BE & 0.807 & 0.874 & 0.637 \\
SAT & 0.910 & 0.944 & 0.848 \\
CR & 0.942 & 0.958 & 0.851 \\
\hline
\end{tabular}

Note: $\mathrm{SMM}=$ Social Media Marketing; PV = Perceived Value; $\mathrm{BE}=$ Brand Equity;

SAT $=$ Satisfaction; CR = Consumer Response

Discriminant validity is a measure of the quality of a measurement instrument. A measurement instrument has good discriminant validity of the statements (or other measures) associated with each latent variable, does not confuse the respondent, and does not have a high correlation with other latent variables (Kock, 2020). Henseler et al. (2015) showed a discriminant validity testing method technique with a heterotrait-monotrait ratio (HTMT) correlation based on a multitrait-multimethod matrix. Therefore, this study evaluates discriminant validity through HTMT. Discriminant validity in this study does not have serious problems when the HTMT value is lower than 0.90 (Gold et al., 2001). All values in Table 2 show the HTMT values between constructs are below 0.90, which indicates that discriminant validity has been achieved. In addition, this study also gives the result that the factor loading of each scale item for the latent construct is higher than the loading on other constructs. This study further strengthens the absence of discriminant validity problems in this study.

Table 2:Results of discriminant validity by HTMT.

\begin{tabular}{|c|c|c|c|c|c|}
\hline Factors & PV & SAT & CR & SMM & $\mathrm{BE}$ \\
\hline PV & & & & & \\
\hline SAT & 0.625 & & & & \\
\hline $\mathrm{CR}$ & 0.414 & 0.320 & & & \\
\hline SMM & 0.822 & 0.681 & 0.309 & & \\
\hline $\mathrm{BE}$ & 0.782 & 0.850 & 0.880 & 0.743 & \\
\hline
\end{tabular}

\section{Inner Model and Hypotheses Testing}

In this study, the inner model is used to test the hypothesis. The Inner Model is used to estimate the path coefficients, R-squares and Q-squares. The path coefficient enables us to see the magnitude and direction of the relationship between latent variables in this study. Social Media Marketing and Brand Equity are second-order factors. The path coefficients in this analysis can be seen in Table 3 and Figure 2. 
It shows that all hypotheses in this study are accepted with a p-value $<0.001$. The $\mathrm{Q}$-squares values for perceived value $(\mathrm{Q} 2=0.474)$, brand equity $(\mathrm{Q} 2=0.363)$, satisfaction $(\mathrm{Q} 2=0.421)$, and consumer response $(\mathrm{Q} 2=0.723)$ are all greater than zero, indicating that this research model has the power good predictor.

Table 3: Summary of inner model results

\begin{tabular}{llll}
\hline Hypothesis & Path coefficient & t-Value & Result \\
\hline H1:SMM $\rightarrow$ PV & 0.689 & 13.787 & Supported \\
H2:SMM $\rightarrow$ SAT & 0.431 & 8.294 & Supported \\
H3:SMM $\rightarrow$ CR & 0.284 & 5.342 & Supported \\
H4:SMM $\rightarrow$ BE & 0.602 & 11.886 & Supported \\
H5:PV $\rightarrow$ SAT & 0.268 & 5.027 & Supported \\
H6:BE $\rightarrow$ CR & 0.988 & 20.666 & Supported \\
\hline
\end{tabular}

Note 1: SMM = Social Media Marketing; PV = Perceived Value; BE = Brand Equity;

$\mathrm{SAT}=$ Satisfaction; $\mathrm{CR}=$ Consumer Response

Note 2: Semua hipotesis memiliki nilai p-value $<0.001$

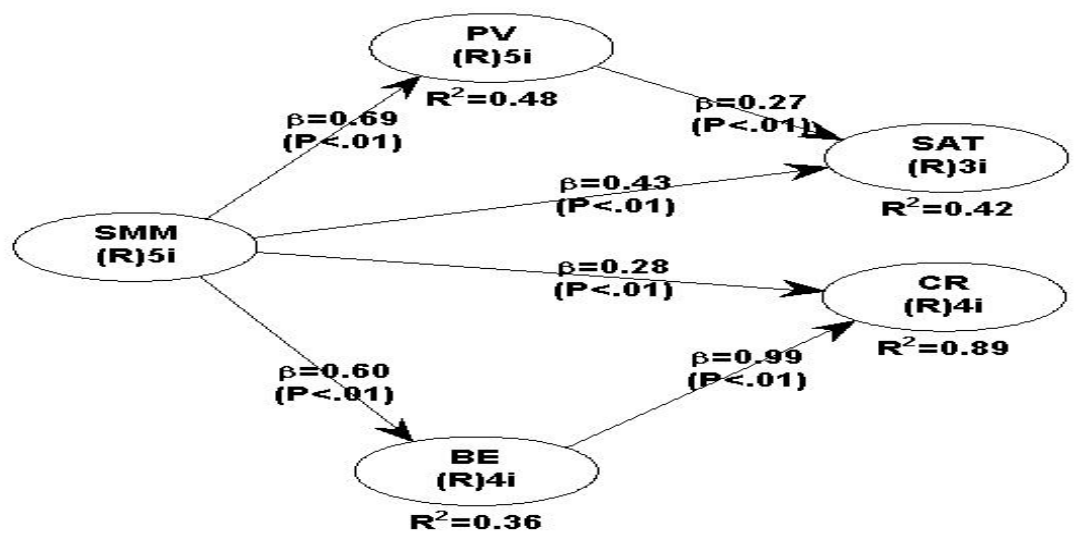

Note 1: $\mathrm{SMM}=$ Social Media Marketing; $\mathrm{PV}=$ Perceived Value; $\mathrm{BE}=$ Brand Equity;

SAT $=$ Satisfaction $; \mathrm{CR}=$ Consumer Response.

Note 2: SMM dan BE adalah Second-order reflective construct

Fig. 2. Standardized path coefficients and significance of inner model

\section{Testing of Mediation Effects}

To test the mediating effect, this study uses the method proposed by Kock (2020). To see whether a mediating effect occurs between variables, Kock (2020) proposes to look at the indirect effect and pvalue. The results of the indirect effect and p-value can be seen in table 4 . Table 4 shows that all p-values are $<0.001$, so it can be stated that the mediating effect in this study is proven.

Table 4: Mediation effects testing

\begin{tabular}{lccc}
\hline Relationship & Indirect effect & Standard errors & p-values \\
\hline $\mathrm{SMM} \rightarrow$ PV $\rightarrow$ SAT & 0.185 & 0.038 & $<0.001$ \\
$\mathrm{SMM} \rightarrow$ BE $\rightarrow$ CR & 0.595 & 0.036 & $<0.001$
\end{tabular}

Note: $\mathrm{SMM}=$ Social Media Marketing; PV = Perceived Value; $\mathrm{BE}=$ Brand Equity;

$\mathrm{SAT}=$ Satisfaction $; \mathrm{CR}=$ Consumer Response 


\section{Discussion and Implication}

This study examines the role of social media marketing in influencing satisfaction and consumer response and looks at the role of brand equity and perceived value as mediation. The results showed that social media marketing affected perceived value. The social media environment encourages user interaction and participation; thus, users are influenced by the website's multimedia, content interaction, and informational content (Keng \& Ting, 2009). Previous literature suggests that companies can use employees and their environment to create experiential settings to stimulate the value and feel of the consumer experience (Keng et al., 2007; Wu \& Liang, 2009). Consumers tend to use social media platforms to purchase by looking for the lowest cost, which brings several significant benefits, i.e., saving money by getting the lowest price, identifying the right product to meet their needs, and comparing other prices from different brands. Therefore, obtaining goods at lower prices is relatively more important for some consumers than product quality or brand image in purchasing decisions (Ismail, 2017).

The results of this study indicate that social media marketing also affects satisfaction. The benefits of social media communities are delivering marketing and customer service information, exploring demand, and managing brand communities. This activity can increase customer satisfaction and improve consumer rights. When conducting online transactions, customers will have higher satisfaction with their website if they have an enjoyable experience (Verhagen et al., 2011). This pleasant experience can be obtained with good social media management from the company's brand. Interaction and communication between users of the social media community will build community loyalty, increase customer satisfaction, and increase customer loyalty, which is the key to long-term management of a social media community platform (McAlexander et al., 2002). The literature's support further confirms that good social media marketing management can increase customer satisfaction.

The influence of social media marketing on consumer response also has a positive effect in this study. Social media is the right platform for consumers to find information to develop preferences about products/brands (Naylor et al., 2012). The more active consumers are on social media, their knowledge of the product/brand will increase. Social media can be a social commerce platform where consumers pay to buy products directly from these social channels (Tuten, 2008). Turning into social commerce will undoubtedly increase consumer response related to existing products/brands. Reich and Pittman (2020) found that the suitability of social media platforms and the resulting attractiveness of social media can increase consumer response through better information processing.

The effect of social media marketing on brand equity is also found in this study. In traditional marketing, companies use communication tools to stimulate consumer perceptions and associations of brands. Through social media, companies can increase awareness, reach new customers and enhance their brand image, contributing to brand value (Godey et al., 2016). Various activities and diversification of social media marketing can thus be assumed to affect the components of customer-based brand equity (Pham \& Gammoh, 2015). Some of the literature above further explains that the better the management of social media marketing, of course, it can increase consumer awareness, consumer associations, and consumer perceptions of the brand, which will boost the brand equity.

Providing superior customer value and customer satisfaction is very important for a company's competitive advantage (Murali et al., 2016). The study of McDougall and Levesque (2000) also discusses the importance of customer perceived value on customer satisfaction. According to them, perceived value is a strong predictor of satisfaction. Perceived value in this study also has a similar finding. In Zeithaml's (1988) view, when customers consider that the benefits they receive are higher than their expenses, they will feel satisfied. The discussion above shows the importance of perceived value in influencing customer satisfaction.

This study also found that brand equity affects consumer response. Consumer perceptions of products/brands can affect consumer response (Buil et al., 2013). Several previous studies have shown that consumer perceptions can produce consumer responses (Kim \& Ko, 2012). Consumer response that 
is often associated with brand equity is brand preference and purchase intention (Raji et al., 2020). Research on the influence of brand equity on consumer response has also been carried out in various fields of business and industry (Raji et al., 2020).

The results of this study provide an essential contribution related to the influence of social media marketing which is still not a priority. In research on social websites, most of them still focus more on eservice quality and website quality. This study confirms that social media marketing activities significantly influence perceived value and brand equity, which in turn affect satisfaction and consumer response. Thus, this model helps to understand the satisfaction and consumer response of social media users. Social media aims to share product/brand information and to increase satisfaction and consumer response and satisfaction. In practice, social media operators have to think about increasing the effectiveness of social media marketing activities. Social media operators are advised to improve their content and activities (for example, test reports for new products, trials for group members, user experience sharing, and a motivational system to increase member engagement). Members can be invited to share their reasons for choosing a brand over a competitor so that others are aware of other competing brands. The resulting discussion gives members more opportunities to consider why they prefer that brand and avoid other brands, thereby strengthening community engagement and brand loyalty.

\section{References}

Agarwal, S., \& Teas, R. K. (2001). Perceived Value: Mediating Role of Perceived Risk. Journal of Marketing Theory and Practice, 9(4), 1-14.

Anderson, J. C., \& Gerbing, D. W. (1988). Structural equation modeling in practice: A review and recommended two-step approach. Psychological bulletin, 103(3), 411.

Atilgan, E., Aksoy, Ş., \& Akinci, S. (2005). Determinants of the brand equity. Marketing Intelligence \& Planning, 23(3), 237-248.

Belén del Río, A., Vázquez, R., \& Iglesias, V. (2001). The effects of brand associations on consumer response. Journal of Consumer Marketing, 18(5), 410-425.

Bruhn, M., Schoenmueller, V., \& Schäfer Daniela, B. (2012). Are social media replacing traditional media in terms of brand equity creation? Management research review, 35(9), 770-790.

Buil, I., Martínez, E., \& de Chernatony, L. (2013). The influence of brand equity on consumer responses. Journal of Consumer Marketing, 30(1), 62-74.

Chen, S.-C., \& Lin, C.-P. (2019). Understanding the effect of social media marketing activities: The mediation of social identification, perceived value, and satisfaction. Technological Forecasting and Social Change, 140, 22-32.

Chin, W. W. (1998). The partial least squares approach to structural equation modeling. Modern methods for business research, 295(2), 295-336.

Cronin, J. J., Brady, M. K., \& Hult, G. T. M. (2000). Assessing the effects of quality, value, and customer satisfaction on consumer behavioral intentions in service environments. Journal of Retailing, 76(2), 193-218.

Ebrahim, R. S. (2020). The role of trust in understanding the impact of social media marketing on brand equity and brand loyalty. Journal of Relationship Marketing, 19(4), 287-308. 
Fornell, C., Johnson, M. D., Anderson, E. W., Cha, J., \& Bryant, B. E. (1996). The American Customer Satisfaction Index: Nature, Purpose, and Findings. Journal of Marketing, 60(4), 7-18.

Fornell, C., \& Larcker, D. F. (1981). Evaluating Structural Equation Models with Unobservable Variables and Measurement Error. Journal of Marketing Research, 18(1), 39-50.

Godey, B., Manthiou, A., Pederzoli, D., Rokka, J., Aiello, G., Donvito, R., \& Singh, R. (2016). Social media marketing efforts of luxury brands: Influence on brand equity and consumer behavior. Journal of Business Research, 69(12), 5833-5841.

Gold, A. H., Malhotra, A., \& Segars, A. H. (2001). Knowledge Management: An Organizational Capabilities Perspective. Journal of Management Information Systems, 18(1), 185-214.

Gunelius, S. (2011). 30-minute social media marketing: Step-by-step techniques to spread the word about your business: Social media marketing in 30 minutes a day. McGraw Hill Professional.

Hair, J. F., Black, W. C., Babin, B. J., \& Anderson, R. E. (2014). Multivariate Data Analysis: Pearson New International Edition, 7th Edition. Pearson Education Limited.

Hanaysha, J. R. (2017). Impact of social media marketing, price promotion, and corporate social responsibility on customer satisfaction. Jindal Journal of Business Research, 6(2), 132-145.

Henseler, J., Ringle, C. M., \& Sarstedt, M. (2015). A new criterion for assessing discriminant validity in variance-based structural equation modeling. Journal of the Academy of Marketing Science, 43(1), 115-135.

Hu, H.-H., Kandampully, J., \& Juwaheer, T. D. (2009). Relationships and impacts of service quality, perceived value, customer satisfaction, and image: an empirical study. The Service Industries Journal, 29(2), 111-125.

Ismail, A. R. (2017). The influence of perceived social media marketing activities on brand loyalty. Asia Pacific Journal of Marketing and Logistics, 29(1), 129-144.

Keng, C. J., Huang, T. L., Zheng, L. J., \& Hsu, M. K. (2007). Modeling service encounters and customer experiential value in retailing. International Journal of Service Industry Management, 18(4), 349-367.

Keng, C. J., \& Ting, H. Y. (2009). The acceptance of blogs: using a customer experiential value perspective. Internet Research, 19(5), 479-495.

Kim, A. J., \& Ko, E. (2010). Impacts of Luxury Fashion Brand's Social Media Marketing on Customer Relationship and Purchase Intention. Journal of Global Fashion Marketing, 1(3), 164-171.

Kim, A. J., \& Ko, E. (2012). Do social media marketing activities enhance customer equity? An empirical study of luxury fashion brand. Journal of Business Research, 65(10), 1480-1486.

Kim, J.-H., \& Hyun, Y. J. (2011). A model to investigate the influence of marketing-mix efforts and corporate image on brand equity in the IT software sector. Industrial marketing management, 40(3), 424-438.

Kock, N. (2020). WarpPLS User Manual: Version 7.0. ScriptWarp Systems.

McAlexander, J. H., Schouten, J. W., \& Koenig, H. F. (2002). Building Brand Community. Journal of Marketing, 66(1), 38-54. 
McDougall, G. H. G., \& Levesque, T. (2000). Customer satisfaction with services: putting perceived value into the equation. Journal of Services Marketing, 14(5), 392-410.

Murali, S., Pugazhendhi, S., \& Muralidharan, C. (2016). Modelling and Investigating the relationship of after sales service quality with customer satisfaction, retention and loyalty - A case study of home appliances business. Journal of Retailing and Consumer Services, 30, 67-83.

Naylor, R. W., Lamberton, C. P., \& West, P. M. (2012). Beyond the "Like" Button: The Impact of Mere Virtual Presence on Brand Evaluations and Purchase Intentions in Social Media Settings. Journal of Marketing, 76(6), 105-120.

Pham, P. H. M., \& Gammoh, B. S. (2015). Characteristics of social-media marketing strategy and customer-based brand equity outcomes: a conceptual model. International Journal of Internet Marketing and Advertising, 9(4), 321-337.

Raji, R. A., Mohd Rashid, S., Mohd Ishak, S., \& Mohamad, B. (2020). Do Firm-Created Contents on Social Media Enhance Brand Equity and Consumer Response Among Consumers of Automotive Brands? Journal of Promotion Management, 26(1), 19-49.

Ravald, A., \& Grönroos, C. (1996). The value concept and relationship marketing. European Journal of Marketing, 30(2), 19-30.

Reich, B. J., \& Pittman, M. (2020). An Appeal to Intimacy: Consumer Response to Platform-Appeal Fit on Social Media. Journal of Consumer Psychology, 30(4), 660-670.

Sano, K. (2014). Does Social Media Enhance Innovation in Customer Relationship Management?: A Theoretical Exploration of The Effects of Social CRM in Service Sectors. Global Marketing Conference, Singapore.

Seo, E.-J., \& Park, J.-W. (2018). A study on the effects of social media marketing activities on brand equity and customer response in the airline industry. Journal of Air Transport Management, 66,36-41.

Tuten, T. L. (2008). Advertising 2.0: Social Media Marketing in a Web 2.0 World. Praeger Publishers.

Tuten, T. L., \& Solomon, M. R. (2018). Social Media Marketing, 3rd Edition. SAGE Publications Ltd.

Verhagen, T., Feldberg, F., van den Hooff, B., Meents, S., \& Merikivi, J. (2011). Satisfaction with virtual worlds: An integrated model of experiential value. Information \& Management, 48(6), 201-207.

Wu, C. H.-J., \& Liang, R.-D. (2009). Effect of experiential value on customer satisfaction with service encounters in luxury-hotel restaurants. International Journal of Hospitality Management, 28(4), 586593.

Yadav, M., \& Rahman, Z. (2018). The influence of social media marketing activities on customer loyalty: A study of e-commerce industry. Benchmarking: An International Journal.

Zeithaml, V. A. (1988). Consumer Perceptions of Price, Quality, and Value: A Means-End Model and Synthesis of Evidence. Journal of Marketing, 52(3), 2-22.

\section{Copyrights}

Copyright for this article is retained by the author(s), with first publication rights granted to the journal.

This is an open-access article distributed under the terms and conditions of the Creative Commons Attribution license (http://creativecommons.org/licenses/by/4.0/). 